\title{
Chile and Japan During the Pinochet Regime, 1974-1989 The Pragmatic Alliance
}

\section{César Ross}

Profesor Titular. Director Doctorado en Estudios Americanos Universidad de Santiago de Chile. cesar.ross@ usach.cl

\begin{abstract}
:
This article is based on an unpublished documents filed in the Historical Archives of the Ministry of Foreign Affairs of Chile for the period 1974-1989. This analysis has enabled file review and refute an important part of the current debate.

This research allows us to affirm that the military regime not only practiced a foreign policy "Praetorian ideological" as he claimed the debate so far, but a pragmatic policy. This policy will not only survive allowed in its period, but survived beyond its end.
\end{abstract}

Keywords: Japan. Chile. International relations. Pinochet regime. Pragmatic alliance.

\section{Sumário}

1 Introduction. 2 Analysis Categories. 2.1 International Isolation. 2.2 The "praetorian-ideological" diplomacy. 2.3 Pragmatic policy with South and East Asia and with Japan. 3 The Topics of the Agenda. 3.1 Local Politics. 3.2 International Politics. 3.3 Economy. 3.4 Cooperation. 4 Conclusion: The failure of the Military Government's Foreign Policy? 5 References. 


\section{INTRODUCTION}

Words to the heat of deeds too cold breath gives (Macbeth, Act II, Scene One).

When I began this research work in 1995, I had a series of convictions sustaining my initial research, which I kept until the year 2000. At that time I found some unpublished documents filed at the Historical Archive of the Ministry for Foreign Affairs of Chile for the period of 19741989.

In general terms, my convictions were at two levels, one at the analysis categories with which the Chilean military government policies had been processed, and the other regarding the issues part of such agenda.

The analysis categories were basically three. First, that the Government and the country had been left in a position of "international isolation". ${ }^{1}$ Second, the military had been unable to act flexibly in the complex international politics, mainly due to their "praetorian-ideological diplomatic style". Third, the only way to overcome the international isolation had been linked to the economic "pragmatic relations structure" basically with East and South Asian countries, to which the local political situation was completely indifferent. ${ }^{2}$ Consequently, and notwithstanding the achievements with East and South Asia, and obviously with Japan, the Military Government's foreign policy was qualified as a complete failure. ${ }^{3}$

${ }^{1}$ Garretón, Manuel Antonio. Incomplete Democracy: Political Democratization in Chile and Latin America. Chapel Hill: University of North Carolina Press, 2003.

${ }^{2}$ Bilateral relations "away from ideologies" were developed with these countries from a classical point of view (typical of the Cold War Era).

3 Togo, Kazuhiko. Japan's Foreign Policy, 1945-2003. The Quest for a Proactive Policy. London: Brill, 2005. 
On the other hand, the issues of the agenda, according to this initial perception, should have been focused on matters related to economic relations, mainly trade and to a lesser extent Japanese investments in Chile.

Now then, the review of this archive has allowed me to go over all these points again and thus conclude that much of this appraisal is to be subject to new interpretations.

\section{ANALYSIS CATEGORIES}

\subsection{International Isolation}

The international isolation of the Military Regime is a quite ambiguous idea which, however, has reached consensus within the academic community and in the public discourse regarding the results of the international policy of the foresaid government.

A solid explanation of the origin of this international isolation is found in a work by Francisco Rojas. This author clearly identifies three elements that explain such isolation: "a) the establishment of an authoritarian project which broke the link between foreign policy and democracy, as well as with human rights as the central axis; b) a diplomacy style characterized as "praetorian-ideological" contrasting with the civil-pragmatic model characteristic of the professional Chilean diplomacy; c) the prosecution and a distinct anticommunist foreign policy at a moment the international system was going into distension". ${ }^{4}$ As it may be concluded from

\footnotetext{
${ }^{4}$ Rojas, Francisco. Chile: Cambio político e inserción internacional. 1964-1997. Estudios Internacionales, n.. 119-120, 1997, p. 388; Joaquín Fermandois. Mundo y Fin de Mundo: Chile en la Política Mundial 1900- 2004. Santiago: Ediciones Universidad Católica de Chile, 2005.
} 
a historical perspective, these factors, either in conjunction or separately, projected into the world scenario and focused on specific and sensitive areas, generated the rejection of the Chilean Military Government.

Under these isolation conditions, and from the perspective of the foreign policy results, Chile would have only succeeded by developing pragmatic alliances and partnerships, linked to the field of economic relations. According to Heraldo Muñoz, one of the authors who claims this thesis, states that this isolation "should be understood not only as the mere absence of international contact, but also as the inability of a country to establish and/or maintain positive and dynamic foreign contact. The political isolation of a country implies the deterioration of the internal prestige, which is an intangible element of power of special importance for countries such as Chile, which do not have significant military or economic resources. In the case of Chile, adds the author, such isolation would mean that the government holding the power is unable to meet the national objectives in the international context as easily and successfully as its predecessors did". ${ }^{5}$ According to the latter part of this definition, almost every Chilean government and those of the region would have been isolated on a permanent basis. Based on the first part, however, it should be possible to assume that the Military Government was isolated as of September 11 1973, as an international consequence of the collapse of democracy. This would have resulted in the "deterioration of the internal prestige”, which actually happened. Although Heraldo Muñoz assigned less importance to this dimension of isolation, it is the key to understand how this phenomenon unfolded regarding the relations in which the Military Regime did succeed.

${ }^{5}$ Muñoz, Heraldo. Las relaciones exteriores del gobierno militar chileno. Santiago: ProspelCerc, 1986. p. 12-13. 


\subsection{The "praetorian-ideological" diplomacy}

This hypothesis was based on the fact that the military had been unable to be flexible in the complexity of international politics, mostly because of their "praetorian-ideological" style. Although handling the issues was simple (few variables), there was clarity and it was possible to react. According to Joaquín Fermandois, ${ }^{6}$ this was a combination of "achievement and luck" that was more successful in the face of minor and intermediate powers. However, although including military was not of great help, having economists on the team was a smart move. The continuity of the civil-pragmatic style that professional diplomats did know how to represent had been broken. ${ }^{7}$

Economists and professional diplomats (not always well complemented) continued with a pragmatism which, although blurred by the "praetorian-ideological" style aimed at the Marxist world, offered almost the only achievements the Military Regime could credit to its own success. ${ }^{8}$

\subsection{Pragmatic policy with South and East Asia and with Japan}

The bilateral pragmatism thesis could be applied to the relations between Chile and Japan, but here it is possible to see something more than mere pragmatism. It is evident that from Japan there was a clear option to cooperate with Chile by way of a policy that we could designate

\footnotetext{
${ }^{6}$ Fermandois, Joaquín. De una inserción a otra: Política exterior de Chile 1968-1991. Estudios Internacionales, n.. 96, p. 455, 1991.

${ }^{7}$ Harmer, Tanya. Allende's Chile and the Inter-American Cold War. Chapel Hill: University of Carolina Press, 2011.

${ }^{8}$ Valdés, Juan Gabriel. Pinochet's Economists: The Chicago School of Economics in Chile. Cambridge: Cambridge University Press, 2008.
} 
as "transactional", ${ }^{9}$ based on the exchange of mutual support at multilateral international organisms. However, this attitude was not present in speeches but in conduct. For this reason, the apparent "ideological neutrality" did not seem to have existed..$^{10}$

From the beginning of the Military Regime, Japan requested from Chile its support to place its representatives at international organisms which regularly applied to United Nation organisms. Chile, in turn, chose to request the Japanese help at financial organisms or at Japanese cooperation entities. Seen in perspective, it can be observed that with the Chilean help, Japan sought to legitimize its international status, while Chile looked for economic survival.

The first time that Japan requested Chile's support for one of its candidates at an international organism was only ten days after the new Government had taken office (September 22, 1973), and it was a candidate to the "Program Committee of the United Nations". ${ }^{11}$ Chile accepted, and continued to do it in the future as part of the transactional policy adjustment.

At first, the Chilean diplomacy looked at Japan skeptically, which Ambassador Carlos Besa Lyon very well expressed in early 1975 as follows,

\footnotetext{
${ }^{9}$ North, Douglass C.. Institutions, Institutional Change and Economic Performance. Cambridge: Cambrige University Press, 1990; Furubotn, Eirik; Richter, Rudolf. Institutions and Economic Theory: The Contribution of the New Institutional Economics. Michigan: The University of Michigan Press. p. 47-77.

${ }^{10}$ Hagström, Linus. Enigmatic Power? Relational Power Analysis and Statecraft in Japan's China Policy. Stocholm: University, Stocholm, 2003.

11 "Note $\mathrm{N}^{\circ} 17600$ ". Historical Archive of the Ministry for Foreign Affairs of Chile (HAFAMCh), september 22, 1973.
} 
They will not support attacks against us, nor will they take a risk on our favor. ${ }^{12}$

This perception started to change gradually. Contacts began to get closer to the extent that a Note was sent the following year. This note was about the 31st General Meeting of the United Nations. The Chilean government commented to the Japanese government that there was a new "show" against Chile, especially regarding the matter of human rights. Chile requested from Japan "as much as possible”, the following,

...may spoil this whimsically made-up campaign, and allow for an objective analysis of the events, and thus make it possible for the Japanese Delegation, in the next [United Nations] Conference, to oppose, or at least, refrain from supporting the unfair accusations of which Chile is a victim. ${ }^{13}$

This request reveals well developed diplomatic complicity, and although Japan was very cautious about these messages, even requesting from the Chilean Government further information on the prisoners in Chile, continued with its policy of trading "silence" and "abstentions" for votes to place its representatives at multilateral organisms.

Despite this caution, Japan showed a subtle agreement on political issues. In 1981, for example, it requested Chile's support for the election of a Japanese candidate to the Human Rights Commission of the United Nations. ${ }^{14}$ There was no explicit commitment, but a clear message by asking support from a government highly disputed in this matter.

12 “Secret Internal Memorandum n 5,” HAFAMCh, March 14, 1975.

13 “Note n 16155," HAFAMCh, 1976.

14 “Secret Internal Memorandum n 244/37,” HAFAMCh, March 20, 1981. 
Another way of political support from Japan to Chile was in lobbying at economic multilateral organisms, but whose decisions had a strong political component, such as the World Bank, and the Inter American Development Bank. Japan supported Chile to get loans from both, the World Bank in $1977^{15}$ and $1980,{ }^{16}$ and at the Inter American Development Bank in $1983 .{ }^{17}$

Contrary to what Ambassador Besa Lyon thought, and quoting his own words, Japan did "take a risk" for the Chilean Military Government.

As can be seen (Table \# 1), this cross support got consistent from the beginning, and became significant.

Only rarely was the support requested refused by the counterpart. ${ }^{18}$ However, already by the eighties the Chilean Government started to condition its support to Japan to immediate retributions. These resulted in Japanese support to elect Chilean candidates at less important international organisms, and to get the loans mentioned above. As an almost natural consequence of these coincidences, the bilateral trade became increasingly sustained (Table \# 2, 4, 5, 6 and 7), and only interrupted by the ups and downs of the world economy.

\footnotetext{
${ }^{15}$ For US\$ 42 million. “Regular Internal Memorandum N 52/22,” HAFAMCh, January 24, 1977.

16 “Note n 190/3," HAFAMCh, October 19, 1980.

17 “Note n 36," HAFAMCh, February 8, 1983.

${ }^{18}$ The only case found corresponds to the Chilean refusal to support the Japanese candidate to Director of Terminology of the Customs Cooperation Council, basically because of having previously committed the vote. “Note n 8589," HAFAMCh, May 13, 1983.
} 
Additionally, Japan also gradually increased the volume of its cooperation to Chile in the eighties. ${ }^{19}$ Although this cooperation was focused on supplementing direct investments in the mining, fishing, and forestry sectors, it was also aimed at sectors that only had social profits.

\section{THE TOPICS OF THE AGENDA}

During the period 1974-1989, the bilateral Agenda was around a few topics (Table \# 3 and 8), almost 50\% of which was in matters of international politics, and to a lesser extent in matters regarding economic relations, which only accounted for about $19 \%$ of the Agenda.

The paradox that the relations we thought of as basically economic had a quite high political component is due to the fact that the strategy to offset the international political isolation of the Chilean Military Government not only was the result of the economic pragmatism of the non-state players, but the result of the political pragmatism of governments which, in this case, we could hardly designate as "praetorian-ideological”. Consequently, this strategy shows that the governments, and not the companies, controlled the process. The companies, in turn, backed up and supported the actions taken by the relevant states.

Notwithstanding the above, it is possible to see some worth reviewing nuances regarding the following analysis variables de analysis: local politics, international politics, economy and cooperation.

\footnotetext{
${ }^{19}$ Between 1974 and 1989, the total Japanese investment materialized in Chile amounted to 144,302 million dollars, accounting for only some $4 \%$ of the entire period. See also, Motoo Abe, "La ayuda al extranjero: Un punto de vista disidente", en Akio Hosono, La Economía Japonesa en una época en transición. Barcelona: Japan Echo INC, Inter-Edit, 1995. p. 51-56; David, Arase. Buying Power. The Political Economy of Japan's Foreign Aid. London: Lynne Rienner Publishers, 1995.
} 
From the point of view of the general trend, the number of contacts declined, which is inversely proportional to the expansion of business and the institutionalization of the Chile-Japan Business Cooperation Committee. ${ }^{20}$ The said Committee started to operate in 1979 between private entrepreneurs of both countries, thus replacing the classical the classical relation between Chilean state-run companies and private Japanese companies. The conclusion regarding this apparent dichotomy is mostly explained because as the model was consolidating, the political-diplomatic demand for contacts was decreasing. The result of this was the expansion of the bilateral trade as shown in the tables in the addenda below.

\subsection{Local Politics}

This variable is divided into two sub-variables. One concerns Chile and/or Japan politics, and the other, Japan's policies towards other countries.

In general, the documents reveal that the interests in local politics decreased relative to the perception the military Government had of its own security and survival in power.

Thus, already by the mid eighties there is almost no information on this matter. However, at the beginning of this period there is more information available on the impact of the Coup on Japan, as well as on the identification and neutralization of actions against the Military Government. The first concern was focused on assessing the internal public opinion, both of the state and non-state players, as well as less influent groups. The second was addressed to analyzing the actions of former Government members and those of Salvador Allende's family, in order to assess them and neutralize their impact on the local public opinion.

${ }^{20}$ Ross, César. “Comité Empresarial Chile-Japón,” El Mercurio, October 11, 1999; César Ross, “El Comité Empresarial Chile-Japón: De la liturgia al libre comercio, 1979-1999,” Diplomacia, n. 86, p. 89-111, 2001; César Ross, Chile y Japón, 1973-1989: de la incertidumbre a la alianza estratégica. Santiago: LOM/USACH, 2007; Ross César. "La política chilena hacia Japón, 1990-2010: La relevancia del largo plazo”. In: Artaza, Mario; Ross, César (Eds). La Política Exterior de Chile, 1990-2009: Del aislamiento a la integración global. Santiago: RIL Editores; USACH, 2012. 


\subsection{International Politics}

This variable is made up of five sub-variables: international visits and moments, bilateral support at multilateral organisms, Japanese policy towards Chile, Chilean policy towards Japan, and agreements and treaties.

As stated above, this is the broadest variable both because of the number of sub-variables and the volume of information found (47.9\%).

Here we can see that the main concern of the Military Government was to overcome its isolation by way of the said "transactional" strategy.

We can see that the "bilateral support at multilateral organisms" and the definition of a "Chilean policy towards Japan" were the most important objectives, accounting for about $56 \%$ of the variable. Second to these were "international visits and meetings" and "Japanese policy towards Chile", both accounting for $38 \%$ of the variable. Third with $6.2 \%$ was the topic of the agreements and treaties which, due to their own nature of the matter, had to have a lower frequency.

Up to this point, it is possible to conclude that this part of the Japanese policy of the Military Government was a true "combination of achievement and luck", in which results were gradually increasing in favor of the Chilean Government.

\subsection{Economy}

The economic topics of the Agenda focused on three areas: trade, Japanese investments in Chile, and Japanese loans to the State of Chile. The structure of this variable was clearly biased to trade, which accounted for about $41 \%$ of the topics.

Second, Japanese investments and loan flows to Chile accounted as a whole for $53.7 \%$ of the Agenda concerns. 
Third, and as an issue concerning more during the first years of the Military Government, was the sub-variable regarding the "relations of Japan with other economies" (5.3\%). Basically, because as the results Chile was getting were improving, the tension due to the economic links of Japan with other countries was decreasing. During this early stage, a geopolitical concept of the economic relation may have prevailed.

\subsection{Cooperation}

This variable is divided into three sub-variables, "cooperation from Japan to Chile", "cooperation from Chile to Japan”, and "donations from Japan to Chile”.

In percentages, $70 \%$ of the variable issue was focused cooperation from Japan to Chile". This variable was almost exclusively related to the Japanese interests in the field of its direct investments, namely, mining, and the fishing and forestry sectors.

The "cooperation from Chile to Japan”, and “donations”, usually from Japan to Chile, accounted for $16 \%$ and $14 \%$, respectively.

Consequently, cooperation, more than a sign of friendship and good will (which actually happened), was a clear sign of the Japanese pragmatism in all the scope of this relation.

\section{CONCLUSION: THE FAILURE OF THE MILITARY GOVERNMENT'S FOREIGN POLICY?}

Despite its achievements with South and East Asia, I had concluded up to now that the Military Government's foreign policy had been a complete failure. However, Chile's relations with this region of the world ${ }^{21}$

\footnotetext{
${ }^{21}$ South and East Asia has gradually become a set of industrialized countries since the last third of the $19^{\text {th }}$ Century, almost as a consequence of its scarce natural resources. Chile has been mainly a primary-exporter country, with limited industrialization, and related to the expansion of the said exports.
} 
developed on a non-subjecting basis, and in a more supplementary way than Chile did with the United States, or with other hegemonic power centers with which the country had previous dominating relations.

From this relation, thus configured from the very beginning, and contrary to what had been thought, the Military Government also got ahead in its own strategy to survive in international politics, especially when its early liberal structural changes started to give good results in the mid eighties. At that time, Chile was at an early stage to become a model for the rest of the region.

On the other hand, and once the Military Regime had ended, a long transition to democracy started. This transition, which implied the development of "international reinsertion" (1990-1993) and "economic diplomacy or diplomacy for development” (1994-2009) policies, has reinforced a model made and approved by the Military Government.

For almost twenty years, the democratic governments have not changed the model structurally speaking. The significant difference has not been in the policy itself, but in its results. Furthermore, Chile's internationalization towards South and East Asia, although it began as a reaction to the international isolation from the western world, continued as a result as a genuine conviction in a specific international relations model. This model was pragmatic and pushed by non-state players, which made it possible to anticipate by twenty years what Susan Strange ${ }^{22}$ called the typical world relations of the post Cold War Era. This explains Chile's success in South East Asia and in the rest of the world.

\footnotetext{
${ }^{22}$ Strange, Susan. "Rethinking Structural Change in the International Political Economy: States, Firms and Diplomacy.” In: Stubbs, Richard; Underhill, Geoffrey R. D. (Eds.). Political Economy and the Changing Global Order. London: The McMillan Press, 1994. p. 103-115.
} 
Las palabras congelan con su hálito el calor de los actos. The words, that is, the texts in the said Archive have allowed me to conclude that beyond the interpretative and biased passion of many authors, the sources have revealed some evidence to partly break the analysis made up to now on the Military Government's foreign policy. This also affected the relations that are the reason of this work.

\section{ARCHIVE SOURCES}

Historical Archive of the Ministry of Foreign Affairs of Chile, 1973-1989.

\section{REFERENCES}

Fermandois, Joaquín. "De una inserción a otra: Política exterior de Chile 19681991.” Estudios Internacionales 96 (1991): 433-455.

Muñoz, Heraldo. Las relaciones exteriores del gobierno militar chileno. Santiago: PROSPEL-CERC, 1986.

Rojas, Francisco. “Chile: Cambio político e inserción internacional. 1964-1997.” Estudios Internacionales 119-120 (1997): 376-406.

Ross, César. “Comité Empresarial Chile-Japón.” El Mercurio, October 11, 1999. Ross, César. "El Comité Empresarial Chile-Japón: De la liturgia al libre comercio, 1979-1999.” Diplomacia 86 (2001): 89-111.

Strange, Susan. "Rethinking Structural Change in the International Political Economy: States, Firms and Diplomacy.” In Political Economy and the Changing Global Order, edited by Richard Stubbs, and Geoffrey R.D. Underhill, 103-115, London: The McMillan Press, 1994.

Recebido em: 14/10/2014

Aceito em: 14/12/2014 


\section{ADDENDA}

Table \# 1

Chile -Japan: bilateral support at multilateral organisms, 1973-1989 (actual support received)

\begin{tabular}{|c|c|c|c|}
\hline \multirow{2}{*}{ Year } & \multicolumn{2}{|c|}{ Support Beneficiary } & \multirow{2}{*}{ Total } \\
\cline { 2 - 3 } & Chile & Japan & \\
\hline 1973 & - & 4 & $\mathbf{4}$ \\
\hline 1974 & 2 & 6 & $\mathbf{8}$ \\
\hline 1975 & 1 & 1 & $\mathbf{2}$ \\
\hline 1976 & 2 & - & $\mathbf{2}$ \\
\hline 1977 & 1 & 4 & $\mathbf{5}$ \\
\hline 1978 & - & 3 & $\mathbf{3}$ \\
\hline 1979 & n/a & n/a & n/a \\
\hline 1980 & 1 & 5 & $\mathbf{6}$ \\
\hline 1981 & 1 & 4 & $\mathbf{5}$ \\
\hline 1982 & 3 & 4 & $\mathbf{7}$ \\
\hline 1983 & 4 & 5 & $\mathbf{9}$ \\
\hline 1984 & 2 & 3 & $\mathbf{5}$ \\
\hline 1985 & 2 & 5 & $\mathbf{7}$ \\
\hline 1986 & 1 & 2 & $\mathbf{3}$ \\
\hline 1987 & 2 & 1 & $\mathbf{3}$ \\
\hline 1988 & - & 1 & $\mathbf{1}$ \\
\hline 1989 & 1 & 2 & $\mathbf{3}$ \\
\hline Total & $\mathbf{2 3}$ & $\mathbf{5 0}$ & $\mathbf{7 3}$ \\
\hline
\end{tabular}

Source: Proprietary information, based on data taken from Internal Memoranda, Telex Messages and Notes (regular and secret) of the Historical Archive of Ministry for Foreign Affairs of Chile w.i.: without information. 
Table \# 2

Chile: Total Trade by Areas and Countries, 1970-2000

(in millions of US\$)

\begin{tabular}{|c|c|c|c|c|c|c|c|}
\hline $\begin{array}{l}\text { Region/ } \\
\text { Country }\end{array}$ & 1970 & 1975 & 1980 & 1985 & 1990 & 1995 & 2000 \\
\hline Japan & 177.5 & 236.1 & 876.9 & 581.0 & $1,956.8$ & $3,920.5$ & $3,258.6$ \\
\hline $\mathrm{NICs}^{1 \mathrm{a}}$ & -- & -- & 217.3 & 196.2 & $1,223.2$ & $3,857.4$ & $2,012.0$ \\
\hline South Korea & - & - & 99.5 & 113.5 & 382.0 & $1,424.5$ & $1,341.6$ \\
\hline Hong Kong & - & - & 45.2 & 20.7 & 30.4 & 194.8 & 0.0 \\
\hline Singapore & - & - & - & - & 51.0 & 136.4 & 47.3 \\
\hline Taiwan & - & - & 72.6 & 62.0 & 361.5 & 904.9 & 801.2 \\
\hline ASEAN4 $^{2 \mathrm{~b}}$ & -- & -- & 16.1 & 23.7 & 197.0 & 511.2 & 536.7 \\
\hline Philippines & - & - & 5.3 & 1.3 & 70.9 & 65.6 & 100.2 \\
\hline Indonesia & - & - & 3.2 & 12.7 & 66.6 & 240.8 & 184.5 \\
\hline Malaysia & - & - & 5.2 & 5.2 & 18.9 & 164.8 & 129.0 \\
\hline Thailand & - & - & 2.4 & 4.5 & 40.6 & 190.6 & 123.0 \\
\hline $\begin{array}{l}\text { P e o p } 1 \text { e's } \\
\text { Republic of } \\
\text { China }\end{array}$ & 0.3 & 16.0 & 126.4 & 148.9 & 87.6 & 873.2 & 1.967 .6 \\
\hline NAFTA & 561.9 & 597.7 & $2,304.7$ & $1,725.7$ & $3,281.6$ & $7,311.9$ & $8,533.4$ \\
\hline Canada & 12.0 & 38.5 & 155.4 & 135.0 & 280.5 & 411.1 & 577.5 \\
\hline United States & 508.9 & 536.0 & $2,054.2$ & $1,525.3$ & $2,842.6$ & $6,167.9$ & $6,522.2$ \\
\hline Mexico & 29.1 & 20.6 & 96.1 & 65.7 & 158.5 & 732.9 & $1,433.7$ \\
\hline MERCOSUR $^{3 \mathrm{c}}$ & 243.9 & 328.9 & $1,347.6$ & 698.0 & $1,785.9$ & $2,615.9$ & $6,213.8$ \\
\hline $\begin{array}{l}\text { E u r o p e a n } \\
\text { Union }\end{array}$ & $1,073.8$ & 307.4 & $2,585.0$ & $1,879.5$ & $5,267.5$ & $7,603.8$ & $7,421.2$ \\
\hline $\begin{array}{l}\text { Rest of the } \\
\text { World }\end{array}$ & 126.7 & $1,509.5$ & $2,232.1$ & $1,575.4$ & $2,052.8$ & $5,100.1$ & $6,571.4$ \\
\hline TOTAL & $2,184.1$ & $2,995.6$ & $9,706.1$ & $6,828.4$ & $15,852.4$ & $31,794.0$ & $36,514.7$ \\
\hline
\end{tabular}

Source: Proprietary information, based on figures of the Monthly Bulleting of the Central Bank of Chile.

Table \# 3

Chile and Japan: Emphasis of the Bilateral Agenda, 1974-1989

\begin{tabular}{|l|c|c|}
\hline Variable & $\mathbf{N}^{\circ}$ Mentions & $\%$ \\
\hline Local Politics & 87 & 17.2 \\
\hline International Politics & 242 & 47.9 \\
\hline Economy & 95 & 18.8 \\
\hline Cooperation & 81 & 16.1 \\
\hline Total & 505 & 100.0 \\
\hline
\end{tabular}

Source: Proprietary information, based on data taken from Internal Memoranda, Telex Messages and Notes (regular and secret) of the Historical Archive of the Ministry for Foreign Affairs of Chile. 
Table \# 4

Chile: Selected World Exports, 1973-1982

(countries in percentages and total in millions of US\$)

\begin{tabular}{|l|r|r|r|r|r|}
\hline Year & \multicolumn{1}{|c|}{ Japan } & \multicolumn{1}{c|}{ NICs. } & USA & $\begin{array}{c}\text { Rest of } \\
\text { the World }\end{array}$ & \multicolumn{1}{c|}{ Total } \\
\hline 1973 & 17.67 & 0.05 & 8.61 & 73.67 & 1,231 \\
\hline 1974 & 16.41 & 4.74 & 11.53 & 67.32 & 2,480 \\
\hline 1975 & 11.23 & 0.78 & 8.82 & 79.17 & 1,661 \\
\hline 1976 & 10.74 & 1.57 & 11.09 & 76.61 & 2,083 \\
\hline 1977 & 11.27 & 0.84 & 13.32 & 74.57 & 2,190 \\
\hline 1978 & 11.56 & 4.89 & 13.35 & 70.20 & 2,408 \\
\hline 1979 & 11.05 & 6.19 & 11.00 & 71.76 & 3,763 \\
\hline 1980 & 10.85 & 6.23 & 12.63 & 70.30 & 4,671 \\
\hline 1981 & 10.92 & 6.42 & 15.15 & 67.50 & 3,906 \\
\hline 1982 & 11.86 & 5.11 & 21.59 & 61.45 & 3,710
\end{tabular}

Source: Proprietary information, based on Economic Social Indicators, Central Bank of Chile.

Table \# 5

Chile: Selected World Imports, 1973-1982

(countries in percentages and total in millions of US\$)

\begin{tabular}{|c|r|r|r|r|r|}
\hline Year & \multicolumn{1}{|c|}{ Japan } & \multicolumn{1}{c|}{ NICs. } & \multicolumn{1}{c|}{ USA } & $\begin{array}{c}\text { Rest of the } \\
\text { World }\end{array}$ & \multicolumn{1}{l|}{ Total } \\
\hline 1973 & 3.21 & 0.44 & 16.31 & 80.02 & 1,098 \\
\hline 1974 & 2.54 & 0.71 & 21.75 & 74.99 & 1,911 \\
\hline 1975 & 3.71 & 0.26 & 29.15 & 66.88 & 1,338 \\
\hline 1976 & 11.13 & 0.12 & 23.73 & 65.02 & 1,685 \\
\hline 1977 & 10.97 & 0.49 & 20.41 & 68.12 & 2,271 \\
\hline 1978 & 7.55 & 3.08 & 26.98 & 62.39 & 3,002 \\
\hline 1979 & 7.55 & 3.79 & 22.63 & 66.03 & 4,218 \\
\hline 1980 & 7.23 & 2.76 & 28.58 & 61.44 & 5,124 \\
\hline 1981 & 9.93 & 3.38 & 24.09 & 62.61 & 6,775 \\
\hline 1982 & 5.99 & 4.07 & 23.91 & 66.02 & 3,831 \\
\hline
\end{tabular}

Source: Proprietary information, based on Economic Social Indicators,

Central Bank of Chile. 
Table \# 6

Chile: Selected World Exports, 1983-1997

(countries in percentages and total in millions of US\$)

\begin{tabular}{|r|r|r|r|r|r|}
\hline Year & \multicolumn{1}{|c|}{ Japan } & \multicolumn{1}{c|}{ NICs. } & USA & $\begin{array}{r}\text { Rest of } \\
\text { the World }\end{array}$ & \multicolumn{1}{l|}{ Total } \\
\hline 1983 & 9.08 & 6.09 & 28.24 & 56.59 & 3,836 \\
\hline 1984 & 11.15 & 7.94 & 26.01 & 54.91 & 3,657 \\
\hline 1985 & 10.27 & 10.24 & 22.78 & 56.72 & 3,823 \\
\hline 1986 & 9.95 & 9.47 & 21.67 & 58.91 & 4,222 \\
\hline 1987 & 11.01 & 9.29 & 22.35 & 57.34 & 5,102 \\
\hline 1988 & 12.51 & 8.84 & 19.77 & 58.88 & 7,049 \\
\hline 1989 & 13.68 & 11.84 & 17.77 & 56.71 & 8,193 \\
\hline 1990 & 16.18 & 10.01 & 17.12 & 56.69 & 8,580 \\
\hline 1991 & 18.17 & 11.01 & 17.64 & 53.18 & 9,048 \\
\hline 1992 & 16.86 & 14.22 & 16.29 & 52.63 & 10,126 \\
\hline 1993 & 15.95 & 14.86 & 17.58 & 51.61 & 9,416 \\
\hline 1994 & 16.97 & 15.64 & 17.28 & 50.11 & 11,645 \\
\hline 1995 & 17.67 & 14.73 & 14.44 & 53.16 & 16.446 \\
\hline 1996 & 16.20 & 9.50 & 14.06 & 60.24 & 15,396 \\
\hline 1997 & 15.72 & 12.08 & 15.92 & 56.28 & 17,025 \\
\hline
\end{tabular}

Source: Proprietary information, based on Economic Social Indicators, Central Bank of Chile. 


\section{Table \# 7}

Chile: Selected World Imports, 1983-1997

(countries in percentages and total in millions of US\$)

\begin{tabular}{|r|r|r|r|r|r|}
\hline Year & \multicolumn{1}{|c|}{ Japan } & \multicolumn{1}{c|}{ NICs. } & \multicolumn{1}{c|}{ USA } & $\begin{array}{c}\text { Rest of } \\
\text { the World }\end{array}$ & \multicolumn{1}{l|}{ Total } \\
\hline 1983 & 5.43 & 4.39 & 23.71 & 66.48 & 2,969 \\
\hline 1984 & 8.98 & 3.71 & 21.49 & 65.82 & 3,481 \\
\hline 1985 & 6.27 & 5.92 & 21.77 & 66.04 & 3,007 \\
\hline 1986 & 9.39 & 5.97 & 20.32 & 64.32 & 3,157 \\
\hline 1987 & 9.62 & 7.77 & 19.22 & 63.39 & 4,023 \\
\hline 1988 & 7.96 & 6.26 & 20.35 & 65.43 & 4,924 \\
\hline 1989 & 10.94 & 6.83 & 20.02 & 62.21 & 6,734 \\
\hline 1990 & 7.82 & 5.01 & 18.89 & 68.29 & 7,272 \\
\hline 1991 & 8.41 & 8.34 & 20.58 & 62.66 & 7,686 \\
\hline 1992 & 9.98 & 8.61 & 20.53 & 60.89 & 9,670 \\
\hline 1993 & 8.12 & 9.45 & 22.79 & 59.64 & 10,869 \\
\hline 1994 & 8.76 & 9.46 & 22.94 & 58.84 & 11,501 \\
\hline 1995 & 6.61 & 9.35 & 24.71 & 59.33 & 15,348 \\
\hline 1996 & 5.47 & 5.43 & 23.68 & 65.42 & 17,353 \\
\hline 1997 & 5.58 & 4.89 & 22.95 & 66.58 & 18,888
\end{tabular}

Source: Proprietary information. based on Economic Social Indicators. Central Bank of Chile. 


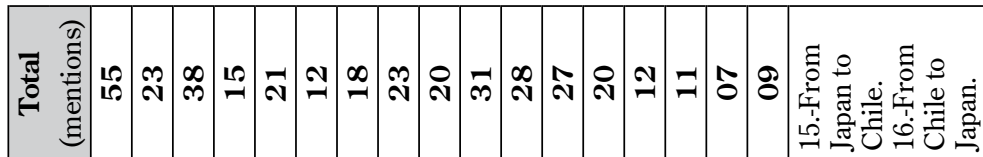

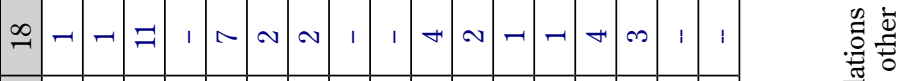

.

으

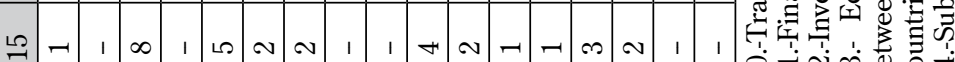

它守

윽 $\infty$ $1-1$ 1 1,1

の

$\infty$
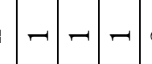

\section{$\sim$ \\ ง}

1

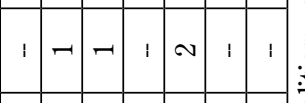

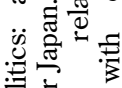

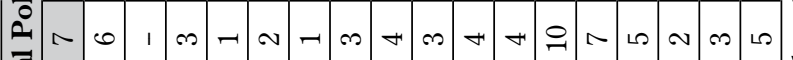

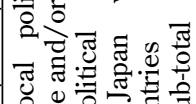

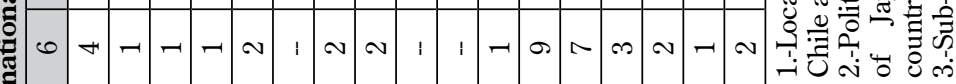

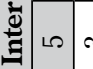

$+$

$1 \sim \sim-1$

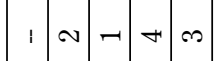

荵急

$\Xi \overbrace{0}^{3}$ व

ம்

를

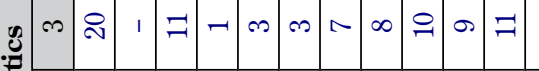

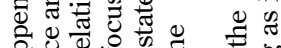

:

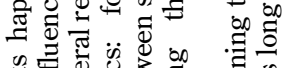
년.

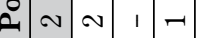
要孚: $\dot{0} \dot{0}=$

త్

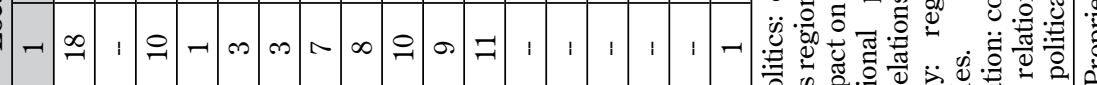

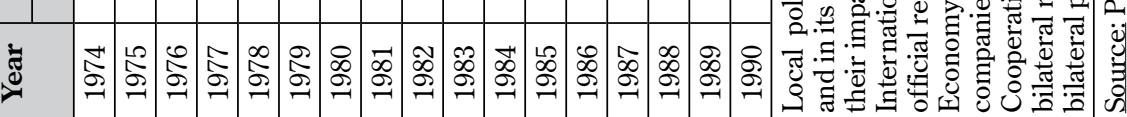

